\title{
Application of Low Pressure Water Scrubbing Technique for Increasing Methane Content in Biogas
}

\author{
Ronald Walozi ${ }^{1, *}$, Betty Nabuuma ${ }^{2}$, Adam Sebiti $^{2}$ \\ ${ }^{1}$ AETREC-Namalere, National Agricultural Research Organisation (NARO), Uganda \\ ${ }^{2}$ Department of Mechanical Engineering, College of Engineering, Design, Art and Technology, Makerere University, Uganda
}

Copyright $\bigcirc 2016$ by authors, all rights reserved. Authors agree that this article remains permanently open access under the terms of the Creative Commons Attribution License 4.0 International License

\begin{abstract}
For many developing nations, biogas has traditionally been used for household cooking and lighting. Methane $\left(\mathrm{CH}_{4}\right)$ content in biogas has to be increased by removing incombustible carbon dioxide $\left(\mathrm{CO}_{2}\right)$ and potentially corrosive constituents such as hydrogen sulphide $\left(\mathrm{H}_{2} \mathrm{~S}\right)$ and moisture. This study set out to increase biogas from $55.8 \% \mathrm{CH}_{4}, 43 \% \mathrm{CO}_{2}, 0.85 \%$ oxygen $\left(\mathrm{O}_{2}\right), 75.1 \mathrm{ppm}$ $\mathrm{H}_{2} \mathrm{~S}$ to $>80 \%$ methane and non-traceable $\mathrm{H}_{2} \mathrm{~S}$ without enhancing raw biogas pressure. By using a single scrubber column and varying water scrubbing system operating parameters of packing material type, packing depth, water and gas flow rates, appropriate parameters for achieving the above objective were determined. The experiments were carried out at an average digester pressure of $1.0589 \mathrm{bar}$. Results show that packing a column with steel-wire mesh to a depth of $0.4 \mathrm{~m}$ increases the volumetric percentage of $\mathrm{CH}_{4}$ in biogas to $>80 \%$ for water to gas flow rate ratios 1.9 and above. Increasing the packed depth to $0.8 \mathrm{~m}$ increases volumetric percentage of $\mathrm{CH}_{4}$ in biogas to $80 \%$ at a lower ratio of 0.7 . This increase in packed depth resulted in an improvement from 1800 litres to 700 litres of water for every $\mathrm{m}^{3}$ of raw biogas upgraded. However, to achieve $>80 \% \mathrm{CH}_{4}$ in marble packed columns of similar depths, the water to gas flow rate ratio has to be raised above 2.5.
\end{abstract}

Keywords Biogas Upgrading, Methane, Packed Column, Renewable Energy, Water Scrubbing

\section{Introduction}

The need to exploit renewable energy sources as a supplement to existing energy supplies in developing nations cannot be overemphasised. Renewables appear to have enormous potential to meet the ever increasing energy needs of the increasing population while offering sustainable solutions for both waste management and global threats of environmental change ${ }^{14}$. Uganda's commitment to this cause is reflected in its renewable energy vision which is to make modern renewable energy a substantial part of the national energy consumption ${ }^{7}$. Among its efforts has been the dissemination of biogas technology.

Raw biogas contains about 55-65\% $\mathrm{CH}_{4}, 30-45 \% \mathrm{CO}_{2}$, $<1 \% \mathrm{H}_{2} \mathrm{~S}$, traces of water vapour ${ }^{5}$ and oxygen ${ }^{11}$. It is produced by anaerobic digestion of organic substrate such as manure, sewage sludge, energy crops and organic fractions of household and industry waste. In Uganda, biogas is mainly generated from animal manure, human waste ${ }^{7}$, grasses, poultry manure and agricultural residues ${ }^{13}$. Since these and other organic wastes are generated on a renewable basis, it would be advantageous to view biogas as a supplementary fuel which can meet Uganda's energy needs ${ }^{8}$.

Biogas is a versatile energy career that finds application at both household and industrial level. It is often utilised in four basic ways; heat and steam production, electricity production and/or co-generation, as a vehicle fuel and for production of chemicals $^{1}$. One of the key factors determining its application is its composition. In its raw form, biogas has low volumetric energy content due to the presence of large quantities of incombustible $\mathrm{CO}_{2}{ }^{17 \& 6}$. This often limits its application to heating and lighting because higher level applications such as vehicle fuel use and electricity generation often require higher percentages of methane. The presence of $\mathrm{CO}_{2}$ makes it hard to compress the gas for storage and also makes its expensive to transport to consumption areas that are not close to biogas production points because a big percentage of the gas has no energy value. Additionally, the presence of $\mathrm{H}_{2} \mathrm{~S}$ makes biogas susceptible to developing corrosive compounds in the presence of water ${ }^{17}$. The potential for raw biogas to form these compounds renders it unsuitable for use in combustion engines for provision of motive power or electricity generation and also complicates compression processes. When biogas systems are set up for simple applications of cooking and lighting, there appears to be no strong incentive for operation and or adoption given the abundance and easy access to other traditional fuels such as firewood or charcoal. Cooking and lighting biogas applications often do not have direct monetary benefits ${ }^{16}$. In order to widen the range of biogas applications that can be accessed by communities, it is necessary to improve its heat content and remove the destructive hydrogen sulphide. Upgraded biogas provides a 
high density energy source with a potential to provide energy inputs to commercial production processes or transport fuel solutions. A number of biogas upgrading methods are already in use. These include; pressure swing adsorption, cryogenic separation, water scrubbing, organic scrubbing, chemical absorption and membrane separation ${ }^{10 \& 12}$. For capital constrained economies, the costs of upgrading should not outweigh the social and economic benefits derived from the upgrading process. According to Patterson et al., the amount of energy required to upgrade raw biogas is a key consideration when selecting an upgrading technology ${ }^{10}$. The lower the energy requirements, the more the net energy available for end use ${ }^{10}$. Several authors have cited water scrubbing as the simplest, cost effective, eco-friendly and practical method for simultaneous removal of $\mathrm{CO}_{2}$ and $\mathrm{H}_{2} \mathrm{~S}$ from biogas ${ }^{4,5 \& 9}$.This technology also offers the possibility of carrying the upgrading process at low gas pressure ${ }^{2}$. These benefits make it well suited for use in rural settings where modern energy is already in short supply.

Water scrubbing is the physical absorption of $\mathrm{CO}_{2}$ and $\mathrm{H}_{2} \mathrm{~S}$ in water at high pressures. It relies on the principle that $\mathrm{H}_{2} \mathrm{~S}$ and $\mathrm{CO}_{2}$ are more soluble in water than $\mathrm{CH}_{4}{ }^{10}$. Water is introduced from the top of the absorption column and biogas is fed from the bottom resulting in a counter-current absorption process ${ }^{6}$. To enhance the effectiveness of the transfer process, packing may be introduced in the column ${ }^{10}$. The water from the column is collected at the bottom. Previous research has shown that water scrubbing using packed beds and pressurised raw biogas can give up to more than $90 \% \mathrm{CH}_{4}$ yield ${ }^{6 \& 11}$. Unlike methods such as pressure swing adsorption, water scrubbing simultaneously removes $\mathrm{CO}_{2}$ and $\mathrm{H}_{2} \mathrm{~S}$ in a single stage process ${ }^{6 \& 12}$. The absorption of gases in water is among other things a function of gas and water pressure, gas and water temperature. Gas absorption increases with increase in pressure ${ }^{11}$.Pressurised water impinging on perforated plates, allows for a more uniform distribution of water in the column. The lower the solvent temperature, the higher the gas absorption capacity ${ }^{15}$. However, increasing raw biogas and water pressure and cooling water are all electrical energy consuming processes, a resource that is both expensive and in short supply especially in the rural areas. Including compression, pumping and cooling processes in the system decreases the net energy output from the upgrading process.

The objective of the study was to determine the feasibility of utilising a counter current absorption process in a packed bed to upgrade biogas from cow manure to $80 \% \mathrm{CH}_{4}$ without using additional energy sources for compressing the raw gas, pumping and cooling the water.

\section{Materials and Methods}

\subsection{Absorption Column and Water Supply System}

An absorption column with a height of $2600 \mathrm{~mm}$ and diameter of $150 \mathrm{~mm}$ was constructed based on Dubey's recommendation for a height to diameter ratio between 10 and $133^{3}$. In order to keep the material costs low, a scrubber column height to diameter ratio of 17 was used. A relatively low height was chosen because provision had to be made for an overhead water tank to which water would be supplied from a nearby water tap without using a water pump. Additionally, the diameter was kept small to allow the water spray generated from the overhead tank through a perforated plate to spread over the entire cross-section of the column and prevent gas from rising without getting into contact with water. The water supply system consisted of an overhead tank of 120 litres. The tank was raised to a height of 5.6 meters from the ground and connected to the scrubber through a 1 inch hose. The scrubber column was designed with provision for changing packing material depth and type.

\subsection{Scrubber Column Packing Material}

Preliminary experiments were carried out to compare five packing materials shown in Figure 1. These included; granite stones, candlenut seed, plastic balls and rings, calcite marble and steel wire mesh. There could have been limited or small voids between individual units creating resistance to upward gas flow. The gas was instead of rising, exiting from the water outlet at the bottom of the column. Additionally, the shapes of the stones could have caused the water to form droplets at the edges which would eventually drip without allowing for sufficient contact between the gas and the water. For the plastic balls and rings, the poor wetting characteristics of plastic material may have resulted in inability for water to uniformly distribute itself within the column for the entire packed depth. From these preliminary experimental results, subsequent more comprehensive experiments were carried out using randomly packed calcite marble of $20 \mathrm{~mm}$ diameter and steel wire mesh.

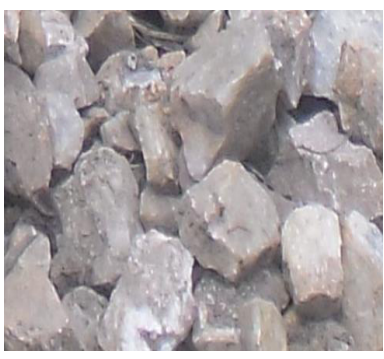

(a)Granite stones $\left(1500 \mathrm{~kg} / \mathrm{m}^{3}\right)$ (Random shapes and sizes)

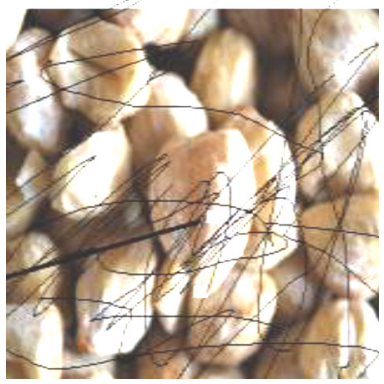

(b) Candle nut seeds $\left(889 \mathrm{~kg} / \mathrm{m}^{3}\right)$ (Random shapes and sizes) 


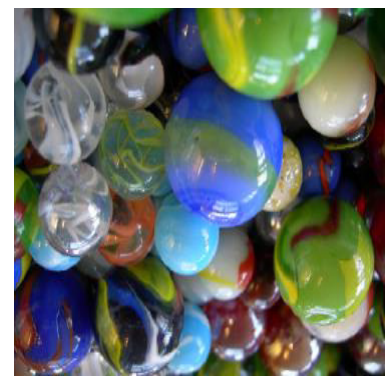

(c) Marble $\left(2500 \mathrm{~kg} / \mathrm{m}^{3}\right)$ (10 and $20 \mathrm{~mm}$ diameter $)$

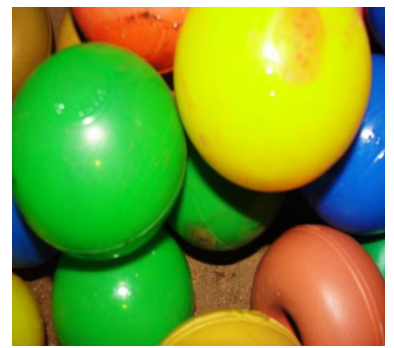

(d)Plastic balls and rings) $\left(800 \mathrm{~kg} / \mathrm{m}^{3} 75 \mathrm{~mm}\right.$ diameter $)$

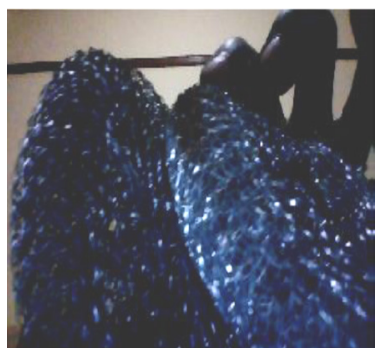

(e) Steel wire mesh packing $\left(178 \mathrm{~kg} / \mathrm{m}^{3}\right)$

Figure 1. Packing materials used

\subsection{Gas Supply System}

Raw biogas was obtained from a $50 \mathrm{~m}^{3}$ fixed dome biogas plants. The gas was delivered to the scrubber column through a $1 / 2$ inch plastic hose with a steel wire mesh filled container between the gas supply system and the scrubber unit to remove some of the hydrogen sulphide before biogas entry into the scrubber column. The gas pressure was then measured using a manometer. Before connecting to the scrubber column, the gas was connected to a MEC CEO 120 LU55BQ gas flow meter capable of measuring between 1 to 10 litres of gas per minute. The composition of the raw biogas was determined using a Geotech biogas analyser capable of providing information on the percentage of $\mathrm{CH}_{4}$, $\mathrm{CO}_{2}, \mathrm{O}_{2}$ and $\mathrm{H}_{2} \mathrm{~S}$. All other components it referred to as balance.

\subsection{Upgrading Parameters}

The effectiveness of the upgrading process was studied for a scrubber column packed with marble of $0.4 \mathrm{~m}$ depth. Raw biogas at a pre-determined gas flow rate was allowed to flow through the packed scrubber column for a period of about 10 minutes to allow for evacuation of resident air through displacement. The water was then allowed to flow at a predetermined rate for about five minutes before samples of the upgraded gas were taken for determination of upgraded biogas composition. For any given water to gas flow rate ratio, output gas composition values were tabulated until there was no or limited variation in the composition of the output. The water flow rate was then adjusted to change the water to gas flow rate ratio. The readings for the new ratio were again taken until there was no significant variation in the composition. This was done for a range of ratios between 0.25 and 2.The procedure explained above was repeated for column packed with $0.8 \mathrm{~m}$ of marble. Thereafter, the packing was changed to steel wire mesh and the upgrading procedure conducted for marble was repeated for steel wire mesh depths of $0.4 \mathrm{~m}$ and $0.8 \mathrm{~m}$.

\subsection{Data Analysis}

Using the tabulated results, percentage $\mathrm{CO}_{2}$ removal and $\mathrm{CH}_{4}$ enrichment for different water to gas flow rate ratios were determined using the formulas ${ }^{11}$.

Percentage carbon dioxide removal

$$
=\frac{y_{p}-y_{r}}{y_{r}} \times 100
$$

Percentage methane enrichment

$$
=\frac{C_{p}-C_{r}}{C_{r}} \times 100
$$

Where $y_{p}$ is carbon dioxide content in processed gas and $y_{r}$ is carbon dioxide content in raw biogas. Where; $C_{p}$ is methane content in processes gas and $C_{r}$ is methane content in raw gas.

\section{Results and Discussions}

\subsection{Characteristics of Raw Biogas and Water}

Table 1 provides a summary of the characteristics of raw biogas and water before the scrubbing process.

Table 1. Characteristics of raw biogas and water

\begin{tabular}{|c|c|}
\hline Biogas & Flow rate (2-6 litres per minute) \\
\hline & Maximum gas pressure (1.0589 bar) \\
\hline & Average temperature $(24$ degrees Celsius $)$ \\
\hline Water & $\begin{array}{c}\text { Percentage Composition }\left(\mathrm{CH}_{4}-55.85 \%, \mathrm{CO}_{2}-43.00 \%, \mathrm{O}_{2}-\right. \\
\left.0.85 \%, \text { Balance- } 0.85 \%, \mathrm{H}_{2} \mathrm{~S}-71.5 \mathrm{ppm}\right)\end{array}$ \\
\hline & $\mathrm{pH}-(6.9)$ \\
\hline & Average temperature (22 degrees Celsius ) \\
\hline
\end{tabular}

\subsection{Performance of Water Upgrading System}

Based on experimental data, Figure 2 shows the relationship between percentage $\mathrm{CO}_{2}$ removal and water to gas flow rate ratio for packing depths of $0.4 \mathrm{~m}$ and $0.8 \mathrm{~m}$. Similarly, Figure 3 shows the relationship between percentage $\mathrm{CH}_{4}$ enrichment and water to gas flow rate ratio for packing depth of $0.4 \mathrm{~m}$ and $0.8 \mathrm{~m}$. Based on the characteristics of raw biogas given in Table 1, and equation 2 in section $2.5,80 \% \mathrm{CH}_{4}$ content in processed gas represents $43.63 \% \mathrm{CH}_{4}$ enrichment. 


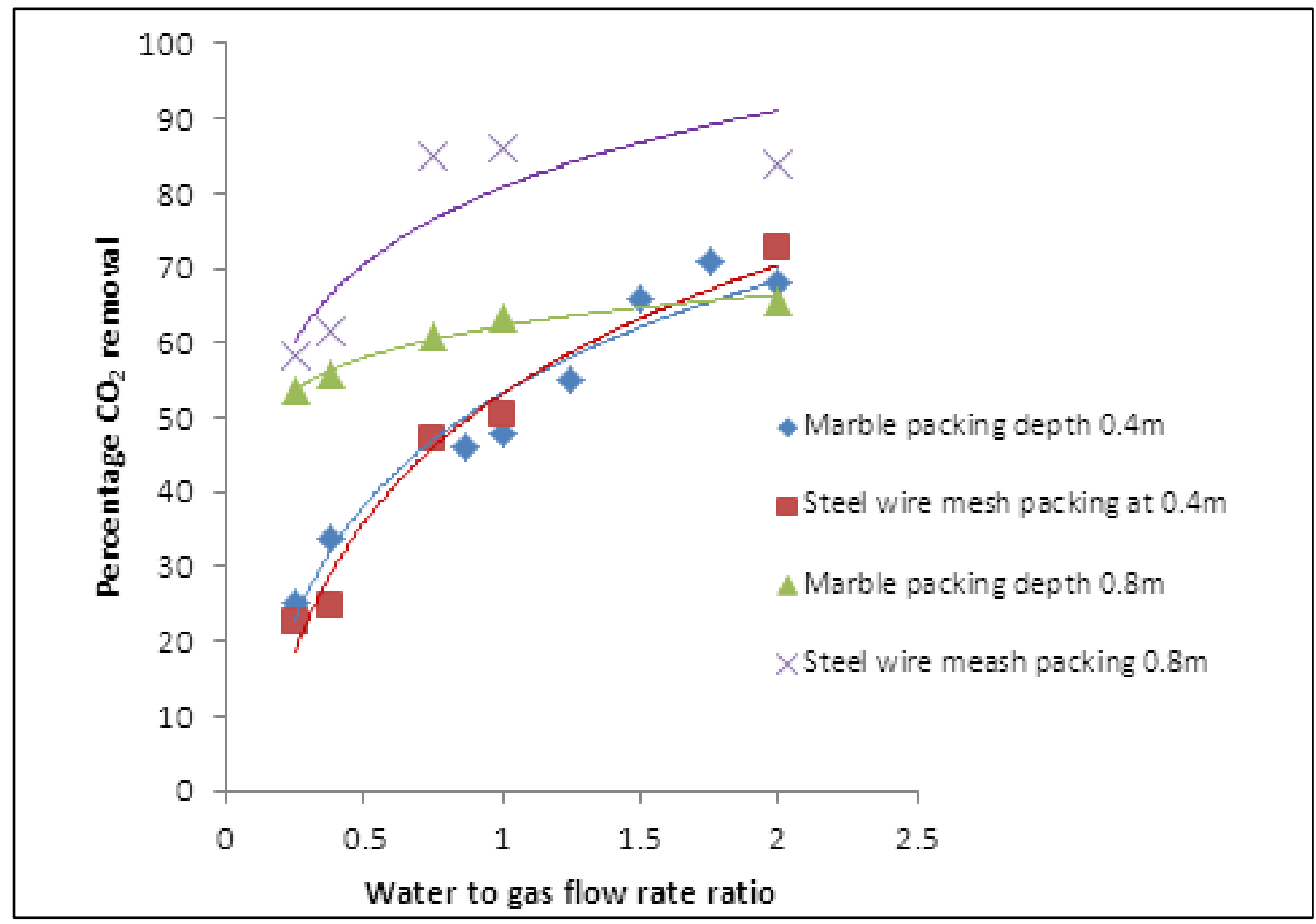

Figure 2. Percentage $\mathrm{CO}_{2}$ removal against water to gas flow rate ratio

Operating at a maximum raw biogas pressure of 1.0589 bar, the upgrading system used in this study was able to raise $\mathrm{CH}_{4}$ content from $55.85 \%$ in raw biogas to $80 \%$ in upgraded biogas without incorporation of an external energy supply for pumping water. A water to gas flow rate ratio of 0.75 resulted in upgraded biogas of $82.2 \% \mathrm{CH}_{4}$ which represents $47.2 \% \mathrm{CH}_{4}$ enrichment. As shown in Figure 3, $43.63 \% \mathrm{CH}_{4}$ enrichment was achieved for water to gas flow rate ratio of 2 using steel wire mesh packing at a depth of $0.4 \mathrm{~m}$. When steel wire mesh packing depth was raised to $0.8 \mathrm{~m}, \mathrm{CH}_{4}$ content increased to $82.2 \%$ with lower water to gas flow rate ratio of 0.75 . This seems to contradict the results of preliminary research studies carried out ${ }^{11}$ Rasiet al. (2008), in which $\mathrm{CH}_{4}$ content observed in the upgraded biogas could not be raised to $80 \%$ when the raw gas pressure was less than 10 bars. However, this variance could have resulted from the difference in the range of water to gas flow rate ratios that were investigated. While this research considered much higher ratios ranging from 0.25 to 2, Rasiet al. (2008) experiments were carried out using gas to water flow rate ratios of 5,10 and $20^{11}$. These translate into water to gas flow rate ratios of $0.2,0.1$ and 0.05 respectively which are below the ratios that were used in the current study.

\subsection{Effect of Packing Material Type and Depth on Product Gas Quality}

The results presented in Figures 2 and 3 indicate that overall, for any water to gas flow rate ratio, effectiveness and efficiency of the upgrading system increases with an increase in packing depth. For example at a water to gas flow rate ratio of 0.25 , the percentage $\mathrm{CH}_{4}$ enrichment increased from $19 \%$ at $0.4 \mathrm{~m}$ packing depth to $27.6 \%$ at $0.8 \mathrm{~m}$ packing depth for marble and from $17.16 \%$ at $0.4 \mathrm{~m}$ packing depth to $34.6 \%$ at $0.8 \mathrm{~m}$ packing depth with steel wire mesh packing material. This means that a $0.4 \mathrm{~m}$ increment in packing depth represents a $45.3 \%$ and $101.6 \%$ improvement in percentage $\mathrm{CH}_{4}$ enrichment for marble and steel respectively. This is because increase in packing depth provides a larger surface area for contact between water and the raw biogas. Additionally, higher packing depth allows for a longer resident time for both fluids in the system which maximises the water's ability to absorb the contaminants from the raw biogas.

Results also show that within the range of water to gas flow rate ratios studied, a similar packing depth increment of $0.4 \mathrm{~m}$ resulted in a larger improvement in the steel mesh packing than for marble. This could be attributed to differences in structure and physical characteristics of the two materials. Compared to marble, steel wire mesh has an open structure with a smaller density. This provides a lower resistance to flow of gas and therefore results in a low pressure drop in steel wire mesh compared to marble packing. 


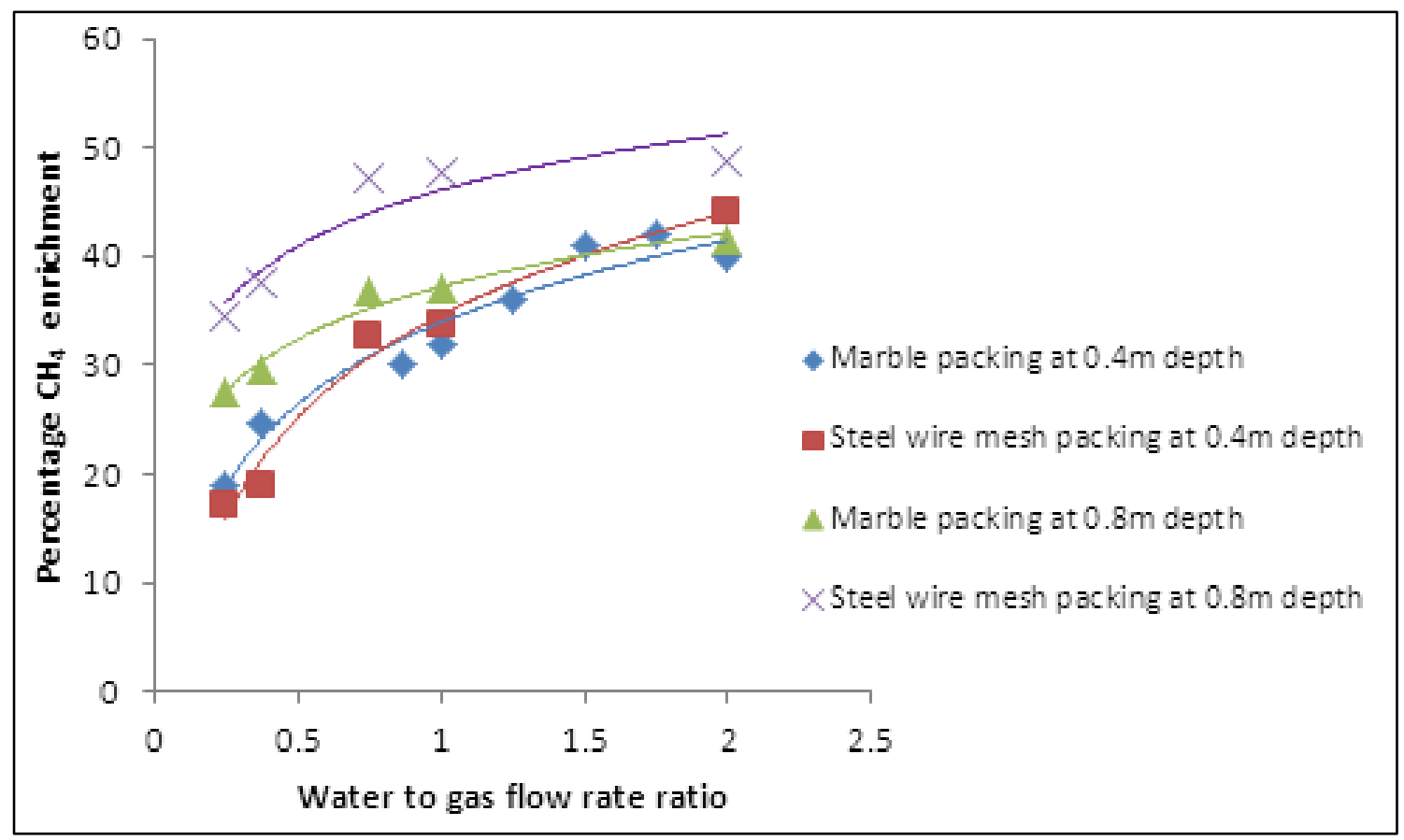

Figure 3. Percentage $\mathrm{CH}_{4}$ enrichment versus water to gas flow rate ratio.

\subsection{Effect of Water to Gas Flow Rate Ratio on Product Gas Quality}

Figures 2 and 3 show that as expected, percentage $\mathrm{CO}_{2}$ removal and resultant $\mathrm{CH}_{4}$ enrichment generally increase with increase in water to gas flow rate ratio. This means that for every unit of biogas flowing through the packed column within a specified time, there is more water available to absorb $\mathrm{CO}_{2}$ at higher water to gas flow rate ratios than for lower ratios. Additionally, higher $\mathrm{CO}_{2}$ absorption at higher water to gas flow rate ratios could be attributed to better spread of gas through the column since at these ratios less gas is flowing through the column per unit time. Although previous research has reported negligible dependency of upgrading efficiency on water to gas flow rate ratio at raw biogas pressures of 10 bar and above ${ }^{11}$ (Rasiet al. 2008), there is a significant dependency between these two parameters when applying low raw biogas pressures such as those used in this study. Figures 2 and 3 reveal a substantial difference in percentage $\mathrm{CO}_{2}$ removed and subsequent $\mathrm{CH}_{4}$ enrichment attained between ratio 0.25 and 0.2 for both packing material type and depth.

Results also indicate that although percentage $\mathrm{CO}_{2}$ removal increases with increase in water to gas flow rate ratio, amount of $\mathrm{CO}_{2}$ absorbed per unit of water utilised decreases with increase in in the ratio. This is evidenced by the decrease in the gradients of the percentage $\mathrm{CO}_{2}$ removal and $\mathrm{CH}_{4}$ enrichment curves as water to gas flow rate ratio increases. For example, a $10 \%$ improvement in $\mathrm{CO}_{2}$ removal is generated in a $0.4 \mathrm{~m}$ steel wire mesh packed column by increasing the ratio from 0.4 to 0.6 . A similar increment in percentage $\mathrm{CO}_{2}$ removal at higher ratios say 1.3 , would require increasing the ratio from 1.3 to 2 . This implies that although upgrading at higher water to gas flow rate ratios is more effective, a more efficient system would require maintaining the process at low water to gas flow rate ratios.

\section{Conclusions}

The results from the study showed that the system was able to reduce the $\mathrm{H}_{2} \mathrm{~S}$ to non-detectible level. Results also revealed that it is possible to use water scrubbing technology to upgrade raw biogas at less than 1.2 bar from $\mathrm{CH}_{4}$ content of $55.85 \%$ to $80 \%$. However, achieving this comes at a very high cost in terms of water. With a scrubber column packed with $0.8 \mathrm{~m}$ deep of steel wire mesh, $80 \%$ methane content was achieved at water to gas flow rate ratio of 0.75 . This ratio implies $750 \mathrm{~m}^{3}$ of water for every $\mathrm{m}^{3}$ of biogas upgraded. Given the cost of water in Uganda which currently stands at Uganda Shilling 2200 (or $\approx$ US \$ 1 ) for every $\mathrm{m}^{3}$ (1000 litres) consumed, water scrubbing under the conditions described in this paper is only suitable where water is free.

The efficiency of the system at raw gas pressures of less than 1.2 bar could be enhanced by adopting a two stage scrubbing process with two packed columns both operating at low flow rate ratios. Since amount of $\mathrm{CO}_{2}$ absorbed per unit of water utilised decreases with increase in water to gas flow rate ratio, using a two stage process would reduce the overall water consumed for every unit of raw biogas upgraded. However, the actual reduction in water consumption for this modification would require investigation.

The largest variable cost in operating the biogas water scrubber is water. One way of sustainably managing the 
process in water- scarce or costly water source regions would be to identify low cost means of regenerating the contaminated water. The water stripped of contaminants would then be reused in the system

\section{REFERENCES}

[1] Baciocchi, R., Carnevale, E., Corti, A., Costa,G., Lombardi, L., Olivieri, T., Zanchi, L., and Zingaretti, D. (2013) "Innovative process for biogas upgrading with $\mathrm{CO}_{2}$ storage: Results from Pilot plant operation" Biomass and Bioenergy 53 pp. 128-137

[2] Cebula J (2009) "Biogas upgrading by sorption techniques" Architecture, Civil Engineering, Environment 2 pp

[3] Dubey, A.K. (2000). Wet scrubbing of Carbon dioxide. Annual report of CIAE, Bhopal, India.

[4] Hunter, p. and Oyama, S. T. (2000). "Control of volatile organic compound emissions. Conventional and Emerging Technologies.” John Wiley \& Sons Inc., New York, USA.

[5] Kapdi, S.S., Vijay, V. K., Rajesh, S.K., Prasad, R. (2006)"Upgrading biogas for utilization as a vehicle fuel" Asian Journal on Energy and Environment 7(04) pp. 387-393

[6] Kapdi, S.S., Vijay, V. K., Rajesh, S.K. and Prasad, R., (2005). "Biogas scrubbing, compression and storage: perspective and prospectus in Indian context". Renewable Energy 3, pp 1195 1202.

[7] Ministry of Energy and Mineral Development (September, 2007), "The Renewable Energy Policy for Uganda" Kampala, Uganda.http://energyandminerals.go.ug/downloads/RENEW ABLE\%20ENERGY\%20POLIC9-11-07.pdf. Last accessed, June 162014.

[8] Nabuuma, B. (2005). "Technical performance Assessment of Biogas Systems in Uganda" Unpublished master's thesis,
Makerere University, Kampala, Uganda.

[9] Ofori-Boateng, C., and Kwofie E. M. (2009) "Water Scrubbing: A Better Option for Biogas Purification for Effective Storage" World Applied Sciences Journal 5 pp. $122-125$

[10] Patterson Tim, Esteves Sandra, Dinsdale Richard, Guwy Alan (2001) "An evaluation of the policy and techno-economic factors affecting the potential for biogas upgrading for transport fuel use in the UK" Energy Policy 39 pp. 1806-1816

[11] Rasi, S. Lantela, J. Veijanen, A. and Rintala, J. (2008). "Landfill gas upgrading with counter current water wash". A Journal on Waste management 28 pp. 1528-1534.

[12] Ryckebosch, E., Drouillon, M. and Vevaeren, C. (2011) "Techniques for transformation of biogas to biomethane" Biomass and Bioenergy 35 pp. 1633-1645

[13] Sengendo, M. Turyahabwe, E. Kato, C. Muganzi, M. Kamara, E. Rugumayo, A. Nyanzi, S. Mubiru, D. and Mussazi, M.,(2010). Programme implementation document for Uganda domestic biogas programme. Heifer International, Kampala Uganda

[14] Shirage P. M., Sankpal S. K and Pawar S. H. (2003) "Biogas plants for fuel cell application" Advances in Renewable energy technologies. Book Chapter edited by Pawar S. H. and Ekal L. A. pp. 269-293

[15] Vijay V. K., Chandra R., Subbarao P. M. V. and Kapdi S.S. (2006) "biogas purification and bottling into CNG cylinders: producing bio-CNG from biomass for rural automotive applications" The 2nd Joint International Conference on "Sustainable Energy and Environment. 21-23 November 2006, Bangkok, Thailand

[16] Vijay, V. K., Prasad, R., Singh, J. P. and Sorayan, V. P. S (1996) "A case for biogas energy application for rural industries in India”. WREC pp. 993-996

[17] Walsh, J.L., Ross, C.C., Smith, M.S., and Harper, S.R. (1989) Utilization of Biogas. Biomass 20.pp. 277-290 